\title{
Addition of a 161-SNP polygenic risk score to family history-based risk prediction: impact on clinical management in non-BRCA1/2 breast cancer families
}

\author{
Inge M M Lakeman, ${ }^{\circledR} 1$ Florentine S Hilbers, ${ }^{1,2}$ Mar Rodríguez-Girondo, ${ }^{3}$ Andrew Lee, ${ }^{4}$ \\ Maaike P G Vreeswijk, ${ }^{\oplus 1}$ Antoinette Hollestelle, ${ }^{5}$ Caroline Seynaeve, ${ }^{5}$ \\ Hanne Meijers-Heijboer, ${ }^{6}$ Jan C Oosterwijk, ${ }^{7}$ Nicoline Hoogerbrugge, ${ }^{8}$ Edith Olah, ${ }^{9}$ \\ Hans F A Vasen, ${ }^{10}$ Christi J van Asperen, ${ }^{11}$ Peter Devilee ${ }^{1,12}$
}

\begin{abstract}
- Additional material is published online only. To view please visit the journal online (http://dx.doi.org/10.1136/ jmedgenet-2019-106072).
\end{abstract}

For numbered affiliations see end of article.

\section{Correspondence to}

Dr Peter Devilee, Human

Genetics, Leids Universitair

Medisch Centrum, Leiden

2333ZA, Netherlands;

p.devilee@lumc.nl

IMML and FSH contributed equally.

Received 8 February 2019 Revised 29 March 2019 Accepted 20 April 2019

\section{Check for updates}

(c) Author(s) (or their employer(s)) 2019. No commercial re-use. See rights and permissions. Published by BMJ.

To cite: Lakeman IMM Hilbers FS,

Rodríguez-Girondo M, et al. $J$ Med Genet Epub ahead of print: [please include Day

Month Year]. doi:10.1136/

jmedgenet-2019-106072

\begin{abstract}
Background The currently known breast cancerassociated single nucleotide polymorphisms (SNPs) are presently not used to guide clinical management. We explored whether a genetic test that incorporates a SNPbased polygenic risk score (PRS) is clinically meaningful in non-BRCA1/2 high-risk breast cancer families.

Methods 101 non-BRCA1/2 high-risk breast cancer families were included; 323 cases and 262 unaffected female relatives were genotyped. The 161-SNP PRS was calculated and standardised to 327 population controls (sPRS). Association analysis was performed using a Cox-type random effect regression model adjusted by family history. Updated individualised breast cancer lifetime risk scores were derived by combining the Breast and Ovarian Analysis of Disease Incidence and Carrier Estimation Algorithm breast cancer lifetime risk with the effect of the SPRS.
\end{abstract}

Results The mean sPRS for cases and their unaffected relatives was $0.70(S D=0.9)$ and $0.53(S D=0.9)$, respectively. A significant association was found between sPRS and breast cancer, $\mathrm{HR}=1.16,95 \% \mathrm{Cl} 1.03$ to $1.28, p=0.026$. Addition of the $s P R S$ to risk prediction based on family history alone changed screening recommendations in $11.5 \%, 14.7 \%$ and $19.8 \%$ of the women according to breast screening guidelines from the USA (National Comprehensive Cancer Network), UK (National Institute for Health and Care Excellence and the Netherlands (Netherlands Comprehensive Cancer Organisation), respectively.

Conclusion Our results support the application of the PRS in risk prediction and clinical management of women from genetically unexplained breast cancer families.

\section{INTRODUCTION}

Breast cancer is the most common cancer in women in the Western world. For women with a first-degree relative with breast cancer, the risk for developing breast cancer is twofold in comparison with women without such a family history. ${ }^{1}$ Approximately $20 \%$ of this familial relative risk is explained by pathogenic variants in the high-risk genes BRCA1 and $B R C A 2,2 \%-5 \%$ by variants in other breast cancer genes (eg, CHEK2, PALB2 and ATM) and $18 \%$ by the currently known common low risk variants, mostly single nucleotide polymorphisms (SNPs). ${ }^{2-5}$

Individually, these SNPs confer a very small increase in breast cancer risk but jointly they may confer a substantial increase of the risk. ${ }^{2}$ This combined risk of all SNPs associated with breast cancer can be summarised in a polygenic risk score (PRS). The PRS can stratify women into different risk categories, ${ }^{26-8}$ which for $8 \%$ of women from the general population might be high enough to be clinically relevant, regardless of family history. ${ }^{2}$

The PRS may also be combined with other risk factors, such as BRCA1/2 status or breast cancer family history, to further refine and individualise risk estimation. The large majority of breast cancer families seen in Family Cancer Clinics today cannot be linked to pathogenic variants in BRCA1 or $B R C A 2$. Risk management for women from these families is based mainly on family history, which can be used as a variable to calculate individual breast cancer risk in various risk prediction algorithms, ${ }^{9}$ such as the Breast and Ovarian Analysis of Disease Incidence and Carrier Estimation Algorithm (BOADICEA). ${ }^{10}$

Until now, the PRS is not included in clinical genetic practice to guide clinical management. Several studies have shown an improved discriminative power between breast cancer cases and controls by combining the PRS with a breast cancer risk prediction tool. ${ }^{11-14}$ However, little is currently known of the discriminative power of the PRS between family members, with respect to who will develop breast cancer. A recent study genotyped cases and controls in 52 Finnish non-BRCA1/2 breast cancer families to calculate a 75-SNP PRS. The PRS for healthy women from breast cancer families was lower in comparison with affected family members. ${ }^{15}$ This suggests that the PRS can help to individualise risk stratification and advice for surveillance for women in breast cancer families.

Here, we explore the clinical applicability of the 161-SNP PRS for risk prediction in a cohort of 101 high-risk breast cancer families not explained by pathogenic variants in the BRCA1 and BRCA2 genes. The clinical impact of the PRS on breast cancer risk prediction based on family history alone was investigated by determining the potential 
change in clinical management, as stipulated by three currently used guidelines (the National Comprehensive Cancer Network guideline $(\mathrm{NCCN}),{ }^{16}$ the National Institute for Health and Care Excellence guideline (NICE) ${ }^{17}$ and the Netherlands Comprehensive Cancer Organisation guideline (IKNL) ${ }^{18}$

\section{MATERIALS AND METHODS Study cohorts}

Two cohorts were included, a hospital-based case-control (Oorsprong van borstkanker integraal onderzocht (ORIGO)) and a family-based case-control cohort. Informed consent was obtained for all individuals. Population controls were irreversibly anonymised. Only women were included in this study.

The ORIGO cohort consists of incident breast cancer cases, not selected for breast cancer family history enrolled between 1996 and 2006 in the context of the ORIGO study, as described elsewhere. ${ }^{19}$ For the present study, 357 ORIGO cases were selected for which genotyping had been performed on the iCOGS array. Likewise, 327 healthy genotyped bloodbank donors were included in the ORIGO cohort as controls. Age of last follow-up was determined as the age at diagnosis for cases and the age at inclusion for controls.

The families from the family-based cohort were selected between 1990 and 2012 through five Clinical Genetic Services (Rotterdam, Groningen, Nijmegen, Leiden, the Netherlands, and Budapest, Hungary) and the Foundation for the Detection of Hereditary Tumours in the Netherlands, as previously described. ${ }^{20}$ At least one family member affected with breast cancer was tested for BRCA1 and BRCA2. We did not have informed consent for testing other specific genes besides BRCA1 and BRCA2. The selection criteria for families included: breast cancer (invasive/in situ) before the age of 60 years in at least three women or in two women if at least one of them had bilateral breast cancer before the age of 60 years. In total, 102 families without a pathogenic variant in BRCA1 or BRCA2 were included of which a blood DNA sample was available for 612 women. Of these women, 340 were affected with breast cancer and 272 were unaffected relatives. The unaffected relatives were censored regarding breast cancer, irrespective of other types of cancer. Most cancers were verified with a pathology report. Date of last follow-up was determined as the date of last contact with the family.

\section{Genotyping}

DNA samples of all included individuals were genotyped with the iCOGS SNP array, designed for association analysis in breast, ovarian and prostate cancer, containing 211155 SNPs. $^{3}$ Genotyping and quality control of the ORIGO cohort was performed as part of association studies conducted by the Breast Cancer Association Consortium (BCAC). ${ }^{3}$ For the family-based cohort, quality control led to the exclusion of 27 individuals (see online supplementary material and methods). Therefore, further analysis was done with 323 breast cancer cases and 262 unaffected relatives from 101 families for this cohort.

\section{Imputation}

Some of the 182 currently known SNPs are associated primarily with oestrogen receptor (ER)-negative or ER-positive breast cancer. We constructed a PRS for overall breast cancer with 161 SNPs, selecting all SNPs significantly associated $\left(\mathrm{p}<5.10^{-8}\right)$ with overall breast cancer in case-control studies performed by $\mathrm{BCAC}^{4}$ (online supplementary table S1). ER status was not known for all cases in our study, and substrata would become too small to reach sufficient statistical power for ER-specific PRSs. The 85 SNPs that were not directly genotyped by the iCOGS array were imputed by prephasing with SHAPEIT and IMPUTE2. ${ }^{21}{ }^{22}$ To improve imputation quality both the reference panels 1000 genomes phase three and Genome of the Netherlands (GoNL) were used. ${ }^{23} 24$

\section{Polygenic risk score}

The following formula was used to calculate the PRS based on 161 SNPs:

$$
P R S_{j}=\sum_{i=1}^{161} n_{i j} \ln \left(O R_{i}\right)
$$

where $n_{i j}$ is the number of risk alleles $(0,1$ or 2$)$ for SNP $i$ carried by individual $j$ and $O R_{i}$ is the per-allele log OR for breast cancer associated with SNP $i$. The ORs were the most recent estimates from analysis of the OncoArray data ${ }^{4}$ (online supplementary table S1). The majority of studies used for this analysis were population-based case-control studies. ${ }^{4}$

The PRS was calculated for all included individuals. For the descriptive analysis, the PRS was standardised to the mean and SD in healthy population controls. The mean standardised PRS (sPRS) in population controls is therefore 0 with an SD of 1. Standardisation facilitates the comparison between different groups. For further analysis in the family-based cohort, the PRS was standardised to the mean and SD in the family-based cohort including both cases and unaffected relatives.

\section{Total BOADICEA score and polygenic load (BOADICEA ${ }_{F H}$ )}

The pedigrees were collected and drawn for all families, including all known first-degree and second-degree relatives of the genotyped individuals. For 25 of the 561 family members affected with breast cancer, the age of breast cancer diagnosis was not known. For these affected family members, the age at diagnosis was assumed to equal the average age of developing breast cancer in the Netherlands (61 years), or the age at last follow-up if this was earlier.

Two different scores were calculated for all individuals in the family cohort by the online risk prediction tool BOADICEA,${ }^{10}$ the total BOADICEA score and the polygenic load. The total BOADICEA score (hereafter termed BOADICEA ${ }_{\mathrm{LTR}}$ ) is a measure for lifetime breast cancer risk and incorporates BRCA1 and BRCA2 status, age, birth cohort and a polygenic load. The polygenic load in the BOADICEA model is an estimated polygenetic component representing a large number of loci of small effect to capture the residual familial aggregation of breast cancer and is therefore a measure of the breast cancer family history. ${ }^{15}$ Calculation of the polygenic load is described previously by Muranen et al. ${ }^{15} \mathrm{To}$ avoid confusion between the variables polygenic load and the PRS, the polygenic load is hereafter termed BOADICEA $_{\mathrm{FH}}$. The BOADICEA $_{\mathrm{LTR}}$ and BOADICEA ${ }_{\mathrm{FH}}$ were calculated by simulating an individual to be at an age of 1 year and unaffected (for cases), that is, lifetime risk at birth, given the family history.

\section{Statistical analysis}

To define the degree of correlation between the sPRS and the BOADICEA $_{\mathrm{FH}}$, the Pearson correlation coefficient was calculated. A Cox-type random effect regression model was used to estimate the association between the sPRS and breast cancer, adjusting by family history, using the BOADICEA $_{\mathrm{FH}}(\mathrm{FH})$ as covariate:

$$
\lambda\left(t_{i j}\right)=u_{i} \lambda_{0}\left(t_{i j}\right) \exp \left(\beta_{1} s P R S_{i j}+\beta_{2} F H_{i j}\right)
$$


where $t_{i j}$ is the age at first diagnosis of breast cancer or the age at censoring for member $j$ in family $i$. Censoring was done at age of last contact with the family or death. Censoring at the age of diagnosis for other tumours, if present, did not affect the result. $\lambda_{0}\left(t_{i j}\right)$ refers to the baseline hazard, which is left completely unspecified (Cox-type model), $\beta_{1}$ is the main effect of interest, the regression coefficient of the sPRS and $\beta_{2}$ is the effect of the BOADICEA $_{\mathrm{FH}}$. In comparing affected to unaffected relatives, it is important to adjust for different numbers of affected versus unaffected relatives per family. We therefore added a family specific random effect $u>0$ in our model, shared by the members of the same family. This unobserved heterogeneity shared within families was assumed to follow a gamma distribution.

To evaluate the potential of the sPRS on the reclassification of breast cancer risk, we constructed a new individual breast cancer risk score based on both the BOADICEA $A_{\text {LTR }}$ and the estimated effect of the sPRS with the model defined by expression 1. Namely, since BOADICEA ${ }_{\text {LTR }}$ is defined as the probability of experiencing breast cancer before age 80 years, the new score is calculated as the distribution function at 80 of a Cox proportional hazard model using BOADICEA ${ }_{\text {LTR }}$ as baseline (average risk in the sample) and the sPRS as covariate:

BOADICEA $_{\mathrm{sPRS}}=1-\left(1-\text { BOADICEA }_{\mathrm{LTR}}\right)^{\wedge}\left(\mathrm{e}\left(\beta_{1} * \mathrm{sPRS}\right)\right)(2)$

The sPRS is expected to individualise cancer risk estimates but not to alter the overall average risk level computed by BOADICEA in the joint sample, that is, the higher risks given to some individuals are expected to be compensated by lower risks in others. For this reason, we centred the sPRS at the mean of the whole family cohort.

The risk calculation based on BOADICEA alone (BOADICE$\mathrm{A}_{\mathrm{LTR}}$ ) and the new individual breast cancer risk score (BOADI$\mathrm{CEA}_{\text {sPRS }}$ ) were compared for all individuals in the family-based cohort to define the change in risk category and thus advice for breast cancer surveillance according to three different guidelines, NICE ${ }^{17} \mathrm{NCCN}^{16}$ and IKNL ${ }^{18}$ (online supplementary table S2).

Statistical significance was established at 5\%, analysis was performed using R V.3.4.1. ${ }^{25}$

\section{RESULTS}

The analysis of the ORIGO cohort included 357 breast cancer cases and 327 population controls. The analysis of the family-based cohort included 323 breast cancer cases and 262 unaffected relatives from 101 families. Unaffected relatives derived from 49 of these 101 families.

\section{Descriptive analysis}

Virtually all breast cancers were invasive in both cohorts, and second breast cancers were more prevalent in familial cases (table 1). In both the ORIGO and family-based cohort, the sPRS was on average higher in cases than in controls (table 2). The unaffected relatives in the family-based cohort had on average a higher sPRS in comparison with ORIGO cases and controls. The mean sPRS for sporadic cases was $0.35(\mathrm{SD}=0.92)$, and in the family-based cohort, the mean sPRS was $0.70(\mathrm{SD}=0.90)$ and $0.53(\mathrm{SD}=0.95)$ for the affected and unaffected relatives, respectively. In the family-based cohort, the sPRS was higher for cases with two invasive breast tumours in comparison with cases with one breast tumour (invasive/in situ), with a mean sPRS of $0.66(\mathrm{SD}=0.89)$ and $0.89(\mathrm{SD}=0.93)$, respectively. The distributions of the sPRS in both cohorts are shown in figure 1. Information about the $95 \%$ CI and SE in different groups are shown in table 2 .

\begin{tabular}{|c|c|c|c|c|}
\hline & \multicolumn{2}{|c|}{ ORIGO cohort } & \multicolumn{2}{|c|}{ Family-based cohort } \\
\hline & Cases & Controls & Cases & $\begin{array}{l}\text { Unaffected } \\
\text { relatives }\end{array}$ \\
\hline Number & 357 & 327 & 323 & 262 \\
\hline \multicolumn{5}{|l|}{ Age } \\
\hline Mean (SD) & $56(10)$ & $46(14)$ & $51(11)$ & $62(17)$ \\
\hline Range & $23-84$ & $18-90$ & $26-90$ & $17-94$ \\
\hline \multicolumn{5}{|l|}{ Country of origin } \\
\hline The Netherlands & 357 & 327 & 317 & 249 \\
\hline Hungary & - & - & 6 & 14 \\
\hline \multicolumn{5}{|l|}{ First breast tumour } \\
\hline Invasive (\%) & $313(88)$ & - & 317 (98) & - \\
\hline DCIS (\%) & $32(9)$ & - & $4(1)$ & - \\
\hline Unknown (\%) & $12(3)$ & - & $2(1)$ & - \\
\hline \multicolumn{5}{|c|}{ Second breast tumour } \\
\hline Invasive (\%) & $19(5)$ & - & $51(16)$ & - \\
\hline DCIS (\%) & $2(1)$ & - & $4(1)$ & - \\
\hline Unknown (\%) & $0(0)$ & - & $5(2)$ & - \\
\hline \multicolumn{5}{|l|}{ Family score } \\
\hline BOADICEA $_{\mathrm{FH}}(\mathrm{SD})$ & - & - & $1.03(0.40)$ & $1.05(0.39)$ \\
\hline BOADICEA $_{\text {LIR }}(S D)$ & - & - & $0.23(0.07)$ & $0.23(0.06)$ \\
\hline
\end{tabular}

BOADICEA $_{\mathrm{FH}^{\prime}}$ Breast cancer family history score; BOADICEA $_{\mathrm{LTR}^{\prime}}$ Breast cancer lifetime risk at age $80 ;$ DCIS, ductal carcinoma in situ.

\section{Correlation}

Further analyses were performed only for the family-based cohort. A weak but statistically significant positive correlation was detected between the BOADICEA $A_{\mathrm{FH}}$ (measure of the family history) and the sPRS. The Pearson correlation coefficient was $0.103,95 \%$ CI 0.022 to $0.183, p=0.013$, which means that $1.1 \%$ of the variance in the sPRS is explained by the BOADICEA $_{\mathrm{FH}}$. Larger correlation was found in the unaffected relatives (correlation coefficient $0.153,95 \%$ CI 0.032 to 0.269 , $\mathrm{p}=0.013)$. No evidence of correlation was found in family cases only (correlation coefficient $0.057,95 \% \mathrm{CI}-0.052$ to 0.165 , $\mathrm{p}=0.306$ ).

\section{Cox-type random effects modelling}

The sPRS should not be directly combined with the BOADICE$A_{\text {ITR }}$ because the PRS is a part of the familial relative risk, captured by BOADICEA by its polygenic component, the BOADICEA $A_{\mathrm{FH}}$. For this reason, adjustment was made by the BOADICEA $_{\mathrm{FH}}$ in the association analysis, using the model defined by expression 1. Furthermore, adjusting for the BOADICEA ${ }_{\mathrm{FH}}$ helps to correct for ascertainment bias. The BOADICEA ${ }_{\mathrm{FH}}$ was calculated for cases assuming they were at age 1 year and unaffected. Consequently controls have, in our sample, a larger BOADICEA ${ }_{\mathrm{FH}}$ than cases. Hence, adding the BOADICEA ${ }_{\mathrm{FH}}$ as a covariate in the model indirectly corrects the oversampling of cases of our design. Within the family-based cohort, the sPRS was significantly associated with breast cancer, conferring an HR of 1.16 ( $95 \%$ CI 1.03 to $1.28 ; \mathrm{p}=0.026$ ) per SD. No statistical significant association was found without adjustment, HR 1.10, 95\% CI 0.98 to $1.23, \mathrm{p}=0.122$.

\section{PRS-based individualised risk score}

To calculate a PRS-based breast cancer risk score (BOADICEA$\left.{ }_{\text {sPRS }}\right)$, the individual sPRS was combined with the BOADICEA ${ }_{\text {LTR }}$. Both risk scores for each individual in the family-based cohort are plotted against each other in figure 2. This resulted in a 
Table 2 Descriptive analysis 161-SNP PRS

\begin{tabular}{|c|c|c|c|c|c|c|}
\hline \multirow[b]{2}{*}{ Group } & \multirow[b]{2}{*}{ Mean sPRS } & \multirow[b]{2}{*}{ SD sPRS } & \multirow[b]{2}{*}{ SE sPRS } & \multirow[b]{2}{*}{$\mathrm{n}$} & \multicolumn{2}{|l|}{$95 \% \mathrm{Cl}$} \\
\hline & & & & & Lower limit & Upper limit \\
\hline Family breast cancer cases & 0.70 & 0.90 & 0.05 & 323 & 0.60 & 0.80 \\
\hline 1 breast tumour & 0.66 & 0.89 & 0.05 & 267 & 0.55 & 0.76 \\
\hline 2 breast tumours & 0.89 & 0.93 & 0.12 & 56 & 0.65 & 1.13 \\
\hline Unaffected relatives & 0.53 & 0.95 & 0.06 & 262 & 0.41 & 0.64 \\
\hline ORIGO cases & 0.35 & 0.92 & 0.05 & 357 & 0.26 & 0.45 \\
\hline Population controls & 0.00 & 1.00 & 0.06 & 327 & -0.11 & 0.11 \\
\hline
\end{tabular}

PRS, polygenic risk score; SNP, single nucleotide polymorphism; sPRS, standardised PRS.

change in breast cancer lifetime risk for all individuals. We evaluated the proportions of individuals that would fall in another risk management category, given risk cut-off levels from three different clinical guidelines. Risk management changed for $19.8 \%, 14.7 \%$ and $11.5 \%$ of women under the IKNL, ${ }^{18} \mathrm{NICE}^{17}$ and $\mathrm{NCCN}^{16}$ guidelines, respectively (table 3 ). The percentage of family cases and unaffected relatives who changed to a lower or higher risk category based on these guidelines are shown in

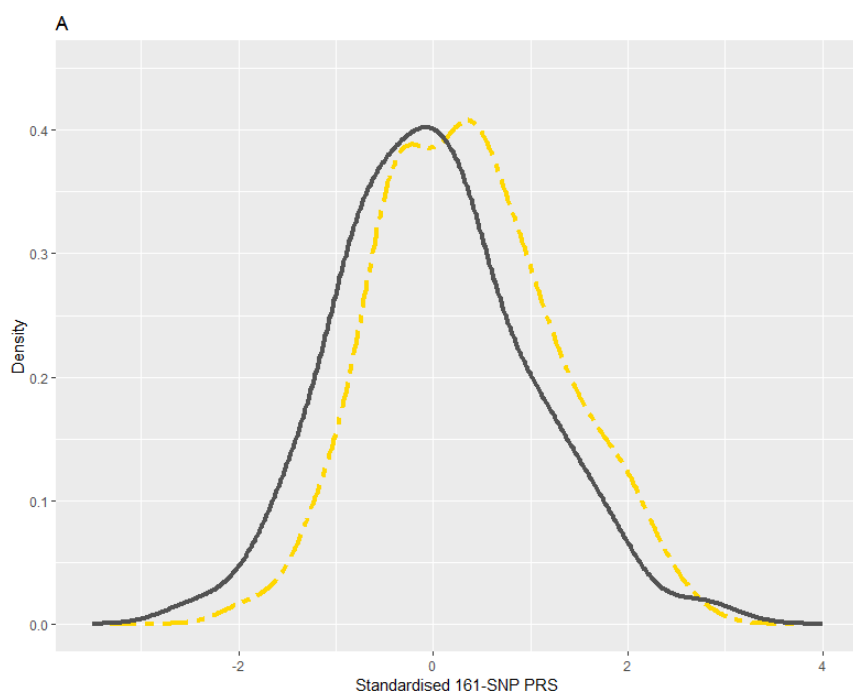

B

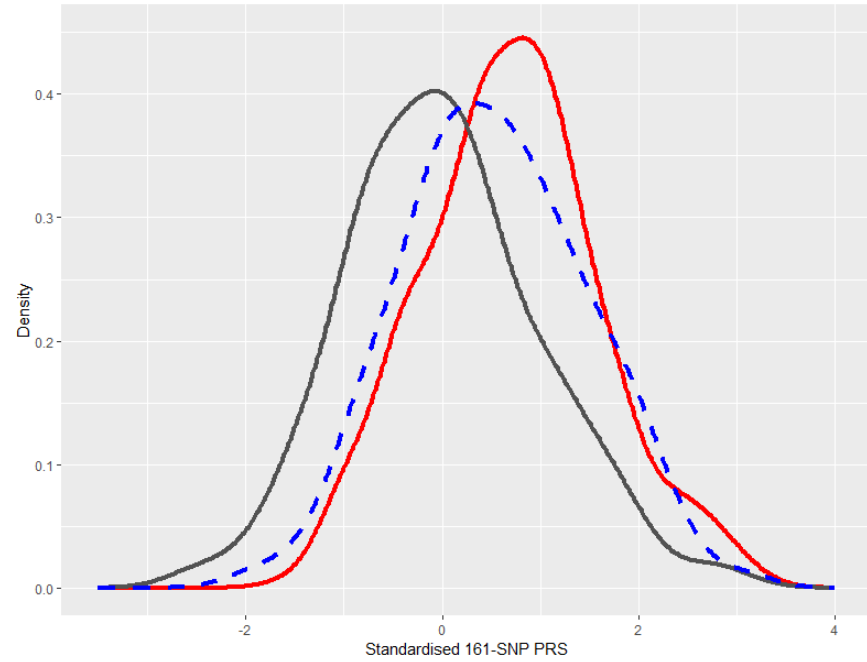

online supplementary table S3. Examples of the change in breast cancer risk category are shown for individuals in three pedigrees in figure 3 and online supplementary table S4.

\section{DISCUSSION}

PRSs, derived from a combination of disease-associated SNPs, are gaining importance as predictive factor for a range of disease

Figure 1 Distribution of the standardised 161-SNP PRS. The standardised 161-SNP PRS was plotted against the density in the different cohorts. (A) Incident breast cancer cases and population controls from the ORIGO cohort; (B) population controls from the ORIGO cohort, breast cancer cases and unaffected relatives from the family-based cohort; (C) population controls from the ORIGO cohort, breast cancer cases with one and two primary breast tumours from the family-based cohort. PRS, polygenic risk score; SNP, single nucleotide polymorphism. 


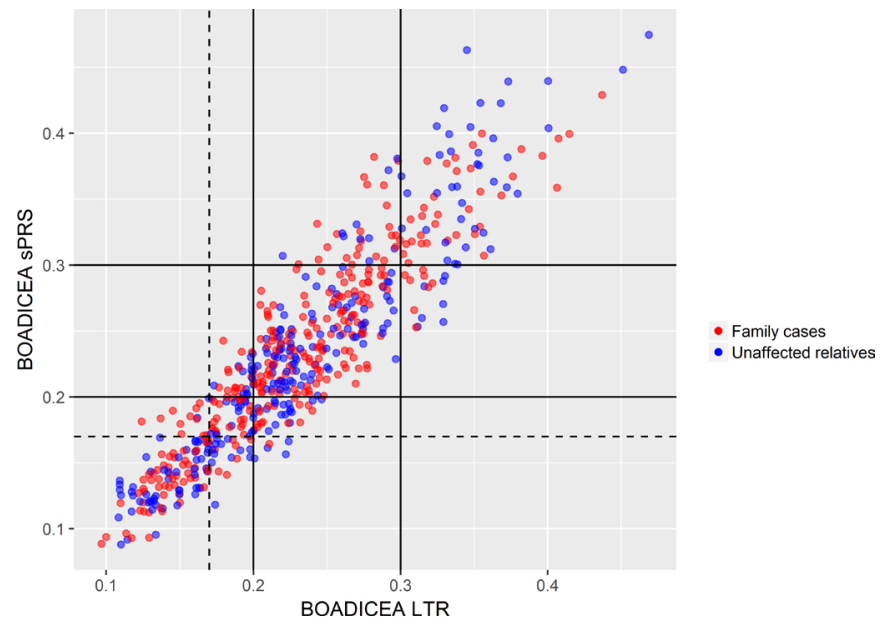

Figure 2 Change in breast cancer lifetime risk score. For every individual, BOADICEA $_{\text {SPRS }}$ was plotted against BOADICEA ${ }_{\text {ITR }}$. The dotted lines represent the $17 \%$ breast cancer lifetime risk cut-off level. The solid lines represent the $20 \%$ and $30 \%$ breast cancer lifetime risk cut-off levels. BOADICEA ${ }_{\text {SPRS }}$ 161-SNP PRS based breast cancer lifetime risk score; BOADICEA ${ }_{\text {ITR' }}$, breast cancer lifetime risk at age 80 , based on BOADICEA alone.

phenotypes, including breast cancer. ${ }^{26}$ All discovered breast cancer SNPs to date explain $18 \%$ of the familial relative risk. ${ }^{4}$ Here, we use a PRS based on these SNPs to show the potential clinical utility within high-risk breast cancer families. While most studies use population controls as a reference group, ${ }^{281213}$ we used the healthy relatives of breast cancer cases as a reference to make it more compatible with clinical practice in Family Cancer Clinics. Similar to population-based case-control studies, ${ }^{2} 1213$ we found that the PRS was significantly associated with breast cancer within high-risk breast cancer families. In addition, the PRS may change breast screening recommendations in a substantial proportion of women from these families, according to currently used screening guidelines. ${ }^{16-18}$ For incompleteness of data on ER status, we did not calculate PRSs predictive for ER-positive or ER-negative disease. ${ }^{5}$ While breast cancer screening guidelines are mainly based on overall breast cancer risk, some guidelines suggest discussing the use of chemoprevention with women at high risk of breast cancer. ${ }^{16}{ }^{17}$ We expect these ER-specific PRSs, similar to the overall PRS, to individualise these discussions within these families.

Some studies have described an association between the PRS and contralateral breast cancer. ${ }^{8}{ }^{28}$ In agreement with this, we found the average sPRS in women diagnosed with two primary breast cancers in our family cohort to be higher in comparison with women with one breast cancer (similarly in ORIGO cases, online supplementary figure S1 and table S5). Thus, the PRS may be helpful managing contralateral breast cancer risk and guide the choice for treatment or risk reducing mastectomy.

The family-based cohort used in our study was not part of the cohort used to discover the breast cancer associated SNPs by GWAS, while the ORIGO cohort was. ${ }^{34}$ A notable finding in our family-based cohort was that unaffected relatives of familial breast cancer cases had on average a higher sPRS than ORIGO incident breast cancer cases, not selected by family history. This may be due to our selection of families with multiple cases of breast cancer, since SNPs of this PRS are expected to cluster in breast cancer families. Moreover, the mean sPRS we calculated for ORIGO cases was lower than found in a large population-based study. ${ }^{2}$ Since we found no evidence for substructures in the ORIGO cohort (online supplementary figure S1 and table S5), this effect is probably due to the relatively small number of ORIGO cases included in this study.

Three previous studies have also genotyped breast cancer cases and their unaffected relatives. ${ }^{7}{ }^{15} 29$ These studies found an association with breast cancer as well, but effect sizes are difficult to compare because of differences in methodology and cohort selection criteria. Furthermore, these studies used a much smaller number of SNPs to calculate the PRS. Li et al analysed a prospective dataset and concluded that their 24-SNP PRS could have altered clinical management in up to $23 \%$ of women, regarding an MRI screening threshold of $20 \%$ breast cancer lifetime risk. Evans et $a^{29}$ performed a case-control study of women attending a familial risk clinic and showed that their 18 -SNP PRS moved 52\% of the controls without a pathogenic

Table 3 Breast cancer risk category change in the family-based cohort

\begin{tabular}{|c|c|c|c|c|c|c|c|}
\hline \multicolumn{2}{|l|}{ Lifetime risk } & \multicolumn{2}{|c|}{$\mathrm{IKNL}^{18}$} & \multicolumn{2}{|c|}{$\mathrm{NICE}^{17}$} & \multicolumn{2}{|c|}{$\mathrm{NCCN}^{16}$} \\
\hline BOADICEA $_{\text {LTR }}$ & BOADICEA $_{\text {SPRS }}$ & $\mathrm{N}$ & $\%$ change & $\mathrm{N}$ & $\%$ change & $\mathrm{N}$ & $\%$ change \\
\hline$<17 \%$ & $<17 \%$ & & & 108 & 10.7 & & \\
\hline$<17 \%$ & $>17 \%$ & & & 13 & & & \\
\hline $17 \%-30 \%$ & $17 \%-30 \%$ & & & 317 & 15.5 & & \\
\hline $17 \%-30 \%$ & $<17 \%$ & & & 24 & & & \\
\hline $17 \%-30 \%$ & $>30 \%$ & & & 34 & & & \\
\hline$<20 \%$ & $<20 \%$ & 175 & 14.2 & & & 175 & 14.2 \\
\hline$<20 \%$ & $>20 \%$ & 29 & & & & 29 & \\
\hline$>20 \%$ & $>20 \%$ & & & & & 343 & 10.0 \\
\hline$>20 \%$ & $<20 \%$ & & & & & 38 & \\
\hline $20 \%-30 \%$ & $20 \%-30 \%$ & 220 & 24.7 & & & & \\
\hline $20 \%-30 \%$ & $<20 \%$ & 38 & & & & & \\
\hline $20 \%-30 \%$ & $>30 \%$ & 34 & & & & & \\
\hline$>30 \%$ & $>30 \%$ & 74 & 16.9 & 74 & 16.9 & & \\
\hline$>30 \%$ & $<30 \%$ & 15 & & 15 & & & \\
\hline Overall change & & & 19.8 & & 14.7 & & 11.5 \\
\hline
\end{tabular}

Following the Dutch IKNL guideline, cut-off levels of $20 \%$ and $30 \%$ represent low, moderate and high risk categories. Following the NICE guideline, $17 \%$ and $30 \%$ represent low, moderate and high risk categories. Following the NCCN guideline, 20\% represent a cut-off level for the high-risk category.

BOADICEA $_{\text {LTR' }^{\prime}}$, breast cancer lifetime risk at age 80, based on BOADICEA alone; BOADICEA SPRS' 161-SNP PRS based breast cancer lifetime risk score; IKNL, Netherlands Comprehensive Cancer Organisation; NCCN, National Comprehensive Cancer Network; NICE, National Institute for Health and Care Excellence. 
A

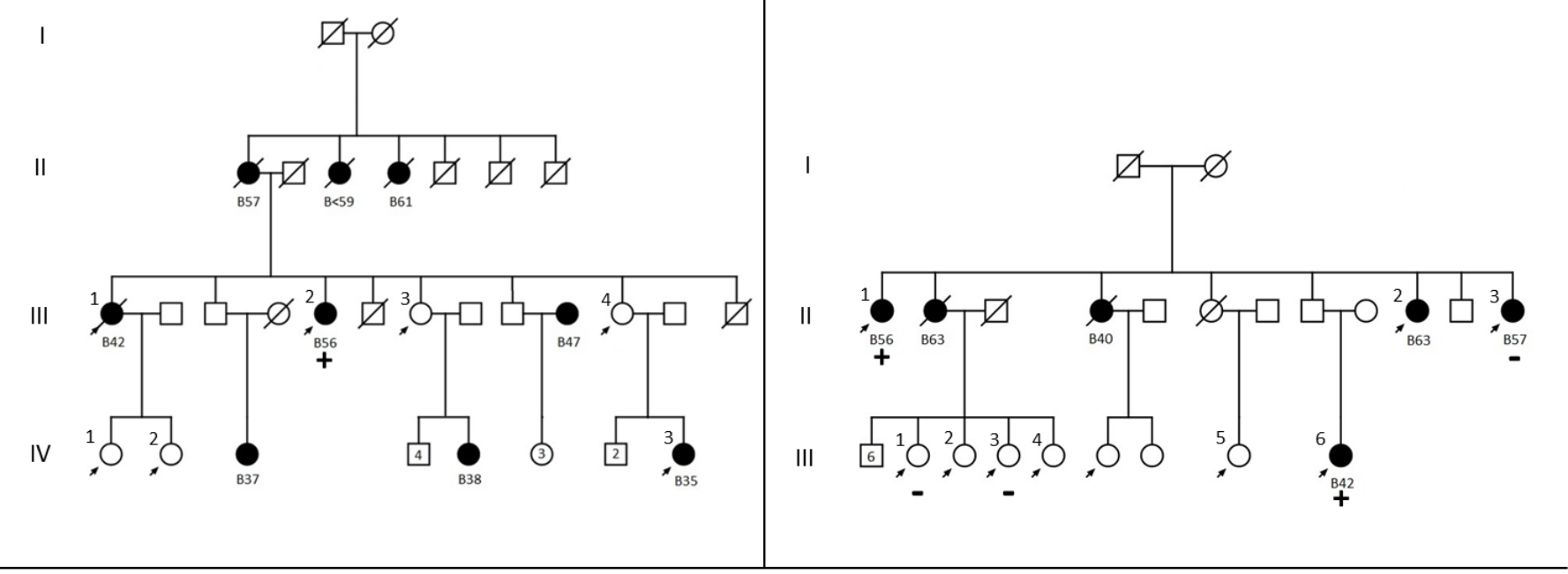

C

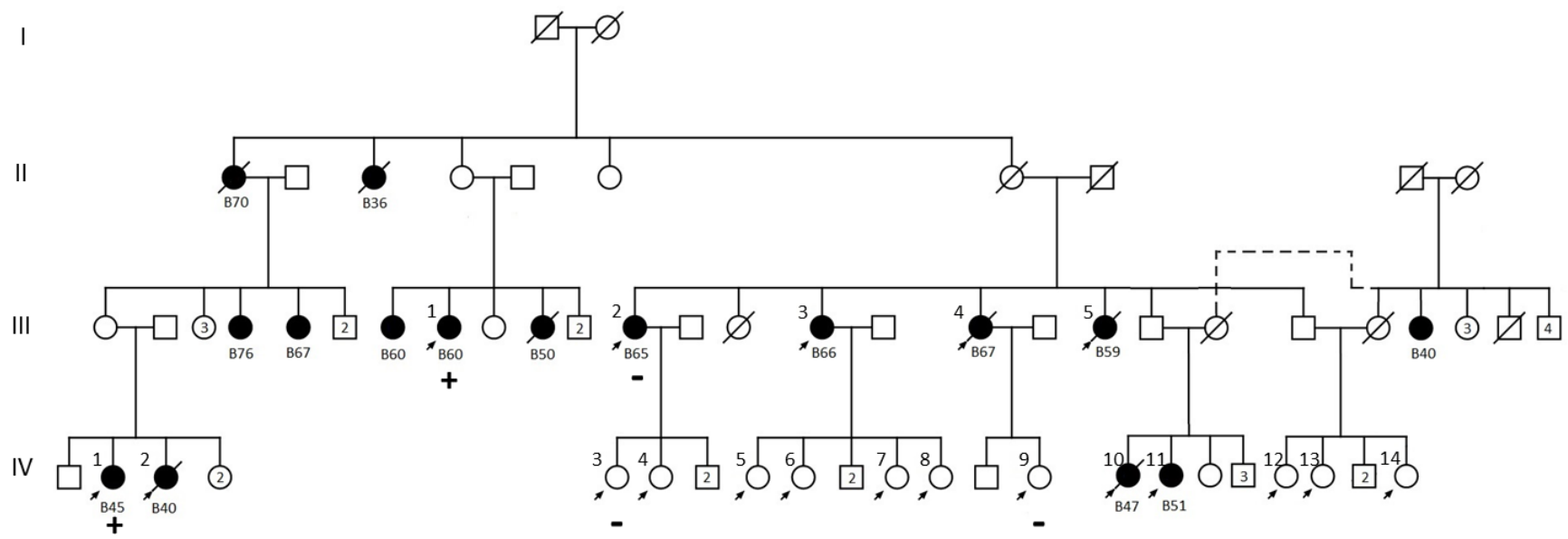

Figure 3 Risk management change for 11 women from three pedigrees. Risk changes are based on the Dutch IKNL screening guideline ${ }^{18}$ (online supplementary table S2). An arrow indicates that a woman has been genotyped. Generations in the pedigree are numbered with I, II, III and IV. Based on the

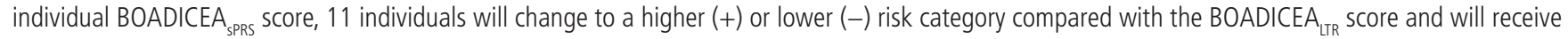

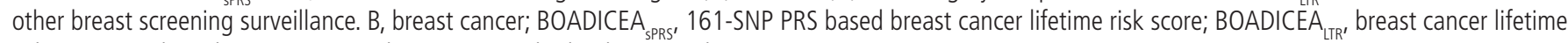
risk at age 80, based on BOADICEA alone; IKNL, Netherlands Comprehensive Cancer Organisation.

variant in BRCA1 or BRCA2 to a different lifetime risk category based on the NICE guideline. ${ }^{17} 29$

In our study, we adopted a conditional approach for association analysis because of the large heterogeneity between the families. Although our use of the BOADICEA $\mathrm{FH}_{\mathrm{FH}}$ adjusts for family history, the HR is probably still underestimated given the strong selection criteria used in our study. Of note, this BOADICEA ${ }_{\mathrm{FH}}$ is not a true family score in a clinical sense, given the retrospective nature of our family cohort. In clinical practice, the risk scores are only calculated for unaffected family members, while in this study, we derive the BOADICEA ${ }_{\mathrm{FH}}$ also for cases, assuming they were at age 1 year and unaffected. With this definition, controls have, in general, a larger BOADICEA ${ }_{\mathrm{FH}}$ than cases. Hence, adding the BOADICEA $\mathrm{FH}_{\mathrm{FH}}$ as a covariate in the model indirectly corrects the oversampling of cases of our design. The same defi-

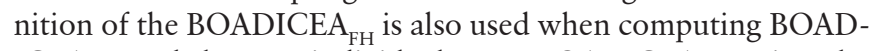
ICEA $_{\text {LTR }}$ and the new individual score BOADICEA ${ }_{\mathrm{sPRS}}$, given by expression 2.

We found that $1.1 \%$ of the variance in the sPRS is explained by the BOADICEA $_{\mathrm{FH}}$. Given that $18 \%$ of the familial relative risk for breast cancer is explained by the currently known SNPs, this is lower than expected. Nonetheless, other studies have also found a weak correlation or no correlation at all between the PRS and the BOADICEA ${ }_{\mathrm{FH}}$ or total BOADICEA score. ${ }^{12} 15$ Thus, BOADICEA appears to be a poor predictor of the PRS, underscoring the value of measuring the PRS for every individual in the family instead of using an estimated PRS based on the total family history.

It is estimated that a large number of SNPs just below the level of genome-wide significance, combined with the currently used 161 SNPs, are able to explain about $41 \%$ of the familial relative risk. ${ }^{4}$ Addition of these SNPs could potentially further refine risk prediction and improve the discriminatory power of the PRS. Studies are now ongoing to find the best performing PRS, including also these SNPs. Khera et $a l^{30}$ found that a PRS of 5218 SNPs associated with breast cancer at a significance level of $<5.10^{-4}$, combined with age, had the best performance based on the area under the receiver-operator curve. Mavaddat et $a l^{31}$ used a hard-thresholding approach to include 313 SNPs at a significance level of $<10^{-5}$. A further improvement for breast cancer risk prediction could come from information on pathogenic variants in non- $B R C A$ high-risk or moderate-risk breast 
cancer genes (eg, PALB2, CHEK2 and ATM). Pathogenic variants in these genes are found in approximately 4\%-6\% of women affected with breast cancer. ${ }^{32} 33$ Recently, the BOADICEA model has been extended with incorporation of the effects of truncating variants in CHEK2, PALB2 and ATM and the 313-SNP based PRS to calculate breast cancer lifetime risks. ${ }^{34}$ A limitation of our study is that we had no ethical approval to test CHEK2, PALB2 and ATM in the studied families. Extrapolating from expected prevalences of pathogenic variants in these genes, we estimate the total percentage of individuals that would have changed to another risk category by addition of the PRS to be $3 \%-4 \%$ higher than the $20 \%$ we report here.

In summary, we showed that the PRS based on the most recently discovered breast cancer SNPs can be used for breast cancer risk prediction within high-risk breast cancer families. Individualising breast cancer risk prediction by adding the individual 161-SNP PRS to family history-based risk prediction may change screening recommendation in up to $20 \%$ of the individuals in these families. While this study illustrates the importance of clinical applicability of the PRS, our results must be interpreted with caution. The HR obtained in this family cohort cannot be translated directly to the clinic as the effect size must be validated in another larger familial breast cancer cohort. Further evaluation, preferably in prospective settings, will be needed.

\section{Author affiliations}

'Department of Human Genetics, Leids Universitair Medisch Centrum, Leiden, The Netherlands

${ }^{2}$ Breast International Group (BIG), Brussels, Belgium

${ }^{3}$ Department of Medical Statistics and Bioinformatics, Leids Universitair Medisch Centrum, Leiden, The Netherlands

${ }^{4}$ Public Health and Primary Care, Centre for Cancer Gentic Epidemiology, Cambridge University, Cambridge, UK

${ }^{5}$ Department of Medical Oncology, Erasmus MC Kanker Instituut, Rotterdam, The Netherlands

${ }^{6}$ Department of Clinical Genetics, VU medisch centrum, Amsterdam, The Netherlands ${ }^{7}$ Department of Genetics, Universitair Medisch Centrum Groningen, Groningen, The Netherlands

${ }^{8}$ Department of Human Genetics, Universitair Medisch Centrum Sint Radboud, Nijmegen, The Netherlands

${ }^{9}$ Department of Molecular Genetics, National Institute of Oncology, Budapest, Hungary

${ }^{10}$ Department of Gastroenterology and Hepatology, Leids Universitair Medisch Centrum, Leiden, The Netherlands

${ }^{11}$ Department of Clinical Genetics, Leids Universitair Medisch Centrum, Leiden, The Netherlands

${ }^{12}$ Department of Pathology, Leids Universitair Medisch Centrum, Leiden, The Netherlands

Acknowledgements We would like to thank Prof. D.F. Easton (University of Cambridge, United Kingdom) for critical review of the manuscript. We would like to thank M.E. Braspenning (Leiden University Medical Centre, the Netherlands) for drawing all pedigrees from the family-based cohort. We would like to thank dr. S. Böhringer and R.L.M. Tissier (Leiden University Medical Centre, the Netherlands) for helpful discussions on statistics at the beginning of the project.

Contributors PD and CvA designed and supervised the project. $\mathrm{AH}, \mathrm{CS}, \mathrm{HMH}, \mathrm{JO}$, $\mathrm{NH}, \mathrm{EO}, \mathrm{HV}$, and CVA have recruited the included breast cancer families and provided the DNA samples. MV, and FH contributed to DNA sample preparation. FH, and IL were responsible for data acquisition. AL has calculated the BOADICEA scores. IL analysed the results with support from MRG. IL, MRG, PD and CVA were involved in data interpretation. IL wrote the manuscript with support from MRG, CVA and PD. All authors read and approved the final manuscript.

Funding This work was supported by the Dutch Cancer Society (KWF), grants UL2009-4388 and UL2014-7473.

Competing interests None declared.

Patient consent for publication Not required.

Provenance and peer review Not commissioned; externally peer reviewed.
Data availability statement Data are available upon reasonable request. No data are available.

\section{REFERENCES}

1 Familial breast cancer: collaborative reanalysis of individual data from 52 epidemiological studies including 58209 women with breast cancer and 101986 women without the disease. The Lancet 2001:358:1389-99.

2 Mavaddat N, Pharoah PDP, Michailidou K, Tyrer J, Brook MN, Bolla MK, Wang Q, Dennis J, Dunning AM, Shah M, Luben R, Brown J, Bojesen SE, Nordestgaard BG, Nielsen SF, Flyger H, Czene K, Darabi H, Eriksson M, Peto J, dos-Santos-Silva I, Dudbridge F, Johnson N, Schmidt MK, Broeks A, Verhoef S, Rutgers EJ, Swerdlow A, Ashworth A, Orr N, Schoemaker MJ, Figueroa J, Chanock SJ, Brinton L, Lissowska J, Couch FJ, Olson JE, Vachon C, Pankratz VS, Lambrechts D, Wildiers H, Van Ongeval C, van Limbergen E, Kristensen V, Grenaker Alnæs G, Nord S, Borresen-Dale A-L, Nevanlinna H, Muranen TA, Aittomäki K, Blomqvist C, Chang-Claude J, Rudolph A, Seibold P, Flesch-Janys D, Fasching PA, Haeberle L, Ekici AB, Beckmann MW, Burwinkel B, Marme F, Schneeweiss A, Sohn C, Trentham-Dietz A, Newcomb P, Titus L, Egan KM, Hunter DJ, Lindstrom S, Tamimi RM, Kraft P, Rahman N, Turnbull C, Renwick A, Seal S, Li J, Liu J, Humphreys K, Benitez J, Pilar Zamora M, Arias Perez Jl, Menéndez P, Jakubowska A, Lubinski J, Jaworska-Bieniek K, Durda K, Bogdanova NV, Antonenkova NN, Dörk T, Anton-Culver H, Neuhausen SL, Ziogas A, Bernstein L, Devilee P, Tollenaar RAEM, Seynaeve C, van Asperen CJ, Cox A, Cross SS, Reed MWR, Khusnutdinova E, Bermisheva M, Prokofyeva D, Takhirova Z, Meindl A, Schmutzler RK, Sutter C, Yang R, Schürmann P, Bremer M, Christiansen H, Park-Simon T-W, Hillemanns P, Guénel P, Truong T, Menegaux F, Sanchez M, Radice P, Peterlongo P, Manoukian S, Pensotti V, Hopper JL, Tsimiklis H, Apicella C, Southey MC, Brauch H, Brüning T, Ko Y-D, Sigurdson AJ, Doody MM, Hamann U, Torres D, Ulmer H-U, Försti A, Sawyer EJ, Tomlinson I, Kerin MJ, Miller N, Andrulis IL, Knight JA, Glendon G, Marie Mulligan A, Chenevix-Trench G, Balleine R, Giles GG, Milne RL, McLean C, Lindblom A, Margolin S, Haiman CA, Henderson BE, Schumacher F, Le Marchand L, Eilber U, Wang-Gohrke S, Hooning MJ, Hollestelle A, van den Ouweland AMW, Koppert LB, Carpenter J, Clarke C, Scott R, Mannermaa A, Kataja V, Kosma V-M, Hartikainen JM, Brenner H, Arndt V, Stegmaier C, Karina Dieffenbach A, Winqvist R, Pylkäs K, Jukkola-Vuorinen A, Grip M, Offit K, Vijai J, Robson M, Rau-Murthy R, Dwek M, Swann R, Annie Perkins K, Goldberg MS, Labrèche F, Dumont M, Eccles DM, Tapper WJ, Rafiq S, John EM, Whittemore AS, Slager S, Yannoukakos D, Toland AE, Yao S, Zheng W, Halverson SL, González-Neira A, Pita G, Rosario Alonso M, Álvarez N, Herrero D, Tessier DC, Vincent D, Bacot F, Luccarini C, Baynes C, Ahmed S, Maranian M, Healey CS, Simard J, Hall P, Easton DF, Garcia-Closas $M$. Prediction of breast cancer risk based on profiling with common genetic variants. JNat/Cancer Inst 2015:107.

3 Michailidou K, Hall P, Gonzalez-Neira A, Ghoussaini M, Dennis J, Milne RL, Schmidt MK, Chang-Claude J, Bojesen SE, Bolla MK, Wang Q, Dicks E, Lee A, Turnbull C, Rahman N, Fletcher O, Peto J, Gibson L, dos Santos Silva I, Nevanlinna H, Muranen TA, Aittomäki K, Blomqvist C, Czene K, Irwanto A, Liu J, Waisfisz Q, Meijers-Heijboer H, Adank M, van der Luijt RB, Hein R, Dahmen N, Beckman L, Meindl A, Schmutzler RK, Müller-Myhsok B, Lichtner P, Hopper JL, Southey MC, Makalic E, Schmidt DF, Uitterlinden AG, Hofman A, Hunter DJ, Chanock SJ, Vincent D, Bacot F, Tessier DC, Canisius S, Wessels LFA, Haiman CA, Shah M, Luben R, Brown J, Luccarini C, Schoof N, Humphreys K, Li J, Nordestgaard BG, Nielsen SF, Flyger H, Couch FJ, Wang X, Vachon C, Stevens KN, Lambrechts D, Moisse M, Paridaens R, Christiaens M-R, Rudolph A, Nickels S, Flesch-Janys D, Johnson N, Aitken Z, Aaltonen K, Heikkinen T, Broeks A, Veer Laura J Van't, van der Schoot CE, Guénel P, Truong T, Laurent-Puig P, Menegaux F, Marme F, Schneeweiss A, Sohn C, Burwinkel B, Zamora MP, Perez JIA, Pita G, Alonso MR, Cox A, Brock IW, Cross SS, Reed MWR, Sawyer EJ, Tomlinson I, Kerin MJ, Miller N, Henderson BE, Schumacher F, Le Marchand L, Andrulis IL, Knight JA, Glendon G, Mulligan AM, Lindblom A, Margolin S, Hooning MJ, Hollestelle A, van den Ouweland AMW, Jager A, Bui QM, Stone J, Dite GS, Apicella C, Tsimiklis H, Giles GG, Severi G, Baglietto L, Fasching PA, Haeberle L, Ekici AB, Beckmann MW, Brenner $H$, Müller H, Arndt V, Stegmaier C, Swerdlow A, Ashworth A, Orr N, Jones M, Figueroa J, Lissowska J, Brinton L, Goldberg MS, Labrèche F, Dumont M, Winqvist R, Pylkäs K, Jukkola-Vuorinen A, Grip M, Brauch H, Hamann U, Brüning T, Radice P, Peterlongo P, Manoukian S, Bonanni B, Devilee P, Tollenaar RAEM, Seynaeve C, van Asperen CJ, Jakubowska A, Lubinski J, Jaworska K, Durda K, Mannermaa A, Kataja V, Kosma V-M, Hartikainen JM, Bogdanova NV, Antonenkova NN, Dörk T, Kristensen VN, Anton-Culver H, Slager S, Toland AE, Edge S, Fostira F, Kang D, Yoo K-Y, Noh D-Y, Matsuo K, Ito H, Iwata H, Sueta A, Wu AH, Tseng C-C, Van Den Berg D, Stram DO, Shu X-O, Lu W, Gao Y-T, Cai H, Teo SH, Yip CH, Phuah SY, Cornes BK, Hartman M, Miao H, Lim WY, Sng J-H, Muir K, Lophatananon A, Stewart-Brown S, Siriwanarangsan P, Shen C-Y, Hsiung C-N, Wu P-E, Ding S-L, Sangrajrang S, Gaborieau V, Brennan P, McKay J, Blot WJ, Signorello LB, Cai Q, Zheng W, Deming-Halverson S, Shrubsole M, Long J, Simard J, Garcia-Closas M, Pharoah PDP, Chenevix-Trench G, Dunning AM, Benitez J, Easton DF. Large-scale genotyping identifies 41 new loci associated with breast cancer risk. Nat Genet 2013:45:353-61.

4 Michailidou K, Lindström S, Dennis J, Beesley J, Hui S, Kar S, Lemaçon A, Soucy P, Glubb D, Rostamianfar A, Bolla MK, Wang Q, Tyrer J, Dicks E, Lee A, Wang Z, Allen J, Keeman R, Eilber U, French JD, Qing Chen X, Fachal L, McCue K, McCart Reed AE, Ghoussaini M, Carroll JS, Jiang X, Finucane H, Adams M, Adank MA, Ahsan H, 
Aittomäki K, Anton-Culver H, Antonenkova NN, Arndt V, Aronson KJ, Arun B, Auer PL, Bacot F, Barrdahl M, Baynes C, Beckmann MW, Behrens S, Benitez J, Bermisheva M, Bernstein L, Blomqvist C, Bogdanova NV, Bojesen SE, Bonanni B, Børresen-Dale A-L, Brand JS, Brauch H, Brennan P, Brenner H, Brinton L, Broberg P, Brock IW, Broeks A, Brooks-Wilson A, Brucker SY, Brüning T, Burwinkel B, Butterbach K, Cai Q, Cai H, Caldés T, Canzian F, Carracedo A, Carter BD, Castelao JE, Chan TL, David Cheng T-Y, Seng Chia K, Choi J-Y, Christiansen H, Clarke CL, Collée M, Conroy DM, Cordina-Duverger E, Cornelissen S, Cox DG, Cox A, Cross SS, Cunningham JM, Czene K, Daly MB, Devilee P, Doheny KF, Dörk T, dos-Santos-Silva I, Dumont M, Durcan L, Dwek M, Eccles DM, Ekici AB, Eliassen AH, Ellberg C, Elvira M, Engel C, Eriksson M, Fasching PA, Figueroa J, Flesch-Janys D, Fletcher O, Flyger H, Fritschi L, Gaborieau V, Gabrielson M, Gago-Dominguez M, Gao Y-T, Gapstur SM, García-Sáenz JA, Gaudet MM, Georgoulias V, Giles GG, Glendon G, Goldberg MS, Goldgar DE, González-Neira A, Grenaker Alnæs GI, Grip M, Gronwald J, Grundy A, Guénel P, Haeberle L, Hahnen E, Haiman CA, Håkansson N, Hamann U, Hamel N, Hankinson S, Harrington P, Hart SN, Hartikainen JM, Hartman M, Hein A, Heyworth J, Hicks B, Hillemanns P, Ho DN, Hollestelle A, Hooning MJ, Hoover RN, Hopper JL, Hou M-F, Hsiung C-N, Huang G, Humphreys $K$, Ishiguro J, Ito $H$, Iwasaki $M$, Iwata $H$, Jakubowska A, Janni W, John EM, Johnson N, Jones K, Jones M, Jukkola-Vuorinen A, Kaaks R, Kabisch M, Kaczmarek K, Kang D, Kasuga Y, Kerin MJ, Khan S, Khusnutdinova E, Kiiski JI, Kim S-W, Knight JA, Kosma V-M, Kristensen VN, Krüger U, Kwong A, Lambrechts D, Le Marchand L, Lee E, Lee MH, Lee JW, Neng Lee C, Lejbkowicz F, Li J, Lilyquist J, Lindblom A, Lissowska J, Lo W-Y, Loibl S, Long J, Lophatananon A, Lubinski J, Luccarini C, Lux MP, Ma ESK, Maclnnis RJ, Maishman T, Makalic E, Malone KE, Kostovska IM, Mannermaa A, Manoukian S, Manson JE, Margolin S, Mariapun S, Martinez ME, Matsuo K, Mavroudis D, McKay J, McLean C, Meijers-Heijboer H, Meindl A, Menéndez P, Menon U, Meyer J, Miao H, Miller N, Taib NAM, Muir K, Mulligan AM, Mulot C, Neuhausen SL, Nevanlinna H, Neven P, Nielsen SF, Noh D-Y, Nordestgaard BG, Norman A, Olopade OI, Olson JE, Olsson H, Olswold C, Orr N, Pankratz VS, Park SK, Park-Simon T-W, Lloyd R, Perez JIA, Peterlongo P, Peto J, Phillips K-A, Pinchev M, Plaseska-Karanfilska D, Prentice R, Presneau N, Prokofyeva D, Pugh E, Pylkäs K, Rack B, Radice P, Rahman N, Rennert G, Rennert HS, Rhenius V, Romero A, Romm J, Ruddy KJ, Rüdiger T, Rudolph A, Ruebner M, Rutgers EJT, Saloustros E, Sandler DP, Sangrajrang S, Sawyer EJ, Schmidt DF, Schmutzler RK, Schneeweiss A, Schoemaker MJ, Schumacher F, Schürmann P, Scott RJ, Scott C, Seal S, Seynaeve C, Shah M, Sharma P, Shen C-Y, Sheng G, Sherman ME, Shrubsole MJ, Shu X-O, Smeets A, Sohn C, Southey MC, Spinelli JJ, Stegmaier C, Stewart-Brown S, Stone J, Stram DO, Surowy H, Swerdlow A, Tamimi R, Taylor JA, Tengström M, Teo SH, Beth Terry M, Tessier DC, Thanasitthichai S, Thöne K, Tollenaar RAEM, Tomlinson I, Tong L, Torres D, Truong T, Tseng C-C, Tsugane S, Ulmer H-U, Ursin G, Untch M, Vachon C, van Asperen CJ, Van Den Berg D, van den Ouweland AMW, van der Kolk L, van der Luijt RB, Vincent D, Vollenweider J, Waisfisz Q, Wang-Gohrke S, Weinberg CR, Wendt C, Whittemore AS, Wildiers H, Willett W, Winqvist R, Wolk A, Wu AH, Xia L, Yamaji T, Yang XR, Har Yip C, Yoo K-Y, Yu J-C, Zheng W, Zheng Y, Zhu B, Ziogas A, Ziv E, Lakhani SR, Antoniou AC, Droit A, Andrulis IL, Amos Cl, Couch FJ, Pharoah PDP, Chang-Claude J, Hall P, Hunter DJ, Milne RL, García-Closas M, Schmidt MK, Chanock SJ, Dunning AM, Edwards SL, Bader GD, Chenevix-Trench G, Simard J, Kraft P, Easton DF. Association analysis identifies 65 new breast cancer risk loci. Nature 2017:551:92-4.

5 Lilyquist J, Ruddy KJ, Vachon CM, Couch FJ. Common genetic variation and breast cancer Risk-Past, present, and future. Cancer Epidemiol Biomarkers Prev 2018;27:380-94.

6 Kuchenbaecker KB, McGuffog L, Barrowdale D, Lee A, Soucy P, Dennis J, Domchek SM, Robson M, Spurdle AB, Ramus SJ, Mavaddat N, Terry MB, Neuhausen SL, Schmutzler RK, Simard J, Pharoah PDP, Offit K, Couch FJ, Chenevix-Trench G, Easton DF, Antoniou AC, Lush M, Hamann U, Southey M, John EM, Chung WK, Daly MB, Buys SS, Goldgar DE, Dorfling CM, van Rensburg EJ, Chun Ding Y, Ejlertsen B, Gerdes AM, Hansen TV, Slager S, Hallberg E, Benitez J, Osorio A, Cohen N, Lawler W, Weitzel JN, Peterlongo P, Pensotti V, Dolcetti R, Barile M, Bonanni B, Azzollini J, Manoukian S, Peissel B, Radice P, Savarese A, Papi L, Giannini G, Fostira F, Konstantopoulou I, Adlard J, Brewer C, Cook J, Davidson R, Eccles D, Eeles R, Ellis S, Frost D, Hodgson S, Izatt L, Lalloo F, Ong KR, Godwin AK, Arnold N, Dworniczak B, Engel C, Gehrig A, Hahnen E, Hauke J, Kast K, Meindl A, Niederacher D, Schmutzler RK, Varon-Mateeva R, Wang-Gohrke S, Wappenschmidt B, Barjhoux L, Collonge-Rame MA, Elan C, Golmard L, Barouk-Simonet E, Lesueur F, Mazoyer S, Sokolowska J, Stoppa-Lyonnet D, Isaacs C, Claes KBM, Poppe B, de la Hoya M, Garcia-Barberan V, Aittomaki K, Nevanlinna H, Ausems M, de Lange JL, Gomez Garcia EB, Hogervorst FB, Kets CM, Meijers-Heijboer HE, Oosterwijk JC, Rookus MA, van Asperen CJ, van den Ouweland AMW, van Doorn HC, van Os TAM, Kwong A, Olah E, Diez O, Brunet J, Lazaro C, Teule A, Gronwald J, Jakubowska A, Kaczmarek K, Lubinski J, Sukiennicki G, Barkardottir RB, Chiquette J, Agata S, Montagna M, Teixeira MR, Kyung Park S, Olswold C, Tischkowitz M, Foretova L, Gaddam P, Vijai J, Pfeiler G, Rappaport-Fuerhauser C, Singer CF, MKM T, Greene MH, Loud JT, Rennert G, Imyanitov EN, Hulick PJ, Hays JL, Piedmonte M, Rodriguez GC, Martyn J, Glendon G, Mulligan AM, Andrulis IL, Toland $A E$, Jenson UB, Kruse TA, Pedersen SI, Thomassen M, Caligo MA, Teo SH, Berger R, Friedman E, Laitman Y, Arver B, Borg A, Ehrancrona H, Rantala J, Olopade OI, Ganz PA, Nussbaum RL, Bradbury AR, Domchek SM, Nathanson KL, Arun BK, James P, Karlan BY, Lester J, Simard J, Pharoah PDP, Offit K, Couch FJ, Chenevix-Trench G, Easton DF, Antoniou AC. Evaluation of polygenic risk scores for breast and ovarian cancer risk prediction in BRCA1 and BRCA2 mutation carriers. J Nat/ Cancer Inst 2017;109. doi:10.1093/jnci/djw302

7 Li H, Feng B, Miron A, Chen X, Beesley J, Bimeh E, Barrowdale D, John EM, Daly MB, Andrulis IL, Buys SS, Kraft P, Thorne H, Chenevix-Trench G, Southey MC, Antoniou AC, James PA, Terry MB, Phillips KA, Hopper JL, Mitchell G, Goldgar DE. Breast cancer risk prediction using a polygenic risk score in the familial setting: a prospective study from the breast cancer family registry and kConFab. Genet Med 2016.

8 Sawyer S, Mitchell G, McKinley J, Chenevix-Trench G, Beesley J, Chen XQ, Bowtell D, Trainer $\mathrm{AH}$, Harris $\mathrm{M}$, Lindeman GJ, James PA. A role for common genomic variants in the assessment of familial breast cancer. JCO 2012:30:4330-6.

9 Cintolo-Gonzalez JA, Braun D, Blackford AL, Mazzola E, Acar A, Plichta JK, Griffin M, Hughes KS. Breast cancer risk models: a comprehensive overview of existing models, validation, and clinical applications. Breast Cancer Res Treat 2017;164:263-84.

10 Lee AJ, Cunningham AP, Kuchenbaecker KB, Mavaddat N, Easton DF, Antoniou AC, Consortium of Investigators of Modifiers of BRCA1/2, Breast Cancer Association Consortium. BOADICEA breast cancer risk prediction model: updates to cancer incidences, tumour pathology and web interface. Br J Cancer 2014;110:535-45.

11 Cuzick J, Brentnall AR, Segal C, Byers H, Reuter C, Detre S, Lopez-Knowles E, Sestak I, Howell A, Powles TJ, Newman WG, Dowsett M. Impact of a panel of 88 single nucleotide polymorphisms on the risk of breast cancer in high-risk women: results from two randomized tamoxifen prevention trials. J Clin Oncol 2017;35:743-50.

12 Dite GS, Macinnis RJ, Bickerstaffe A, Dowty JG, Allman R, Apicella C, Milne RL, Tsimiklis H, Phillips K-A, Giles GG, Terry MB, Southey MC, Hopper JL. Breast cancer risk prediction using clinical models and 77 independent risk-associated SNPs for women aged under 50 years: Australian Breast cancer family registry. Cancer Epidemiol Biomarkers Prev 2016;25.

13 Shieh Y, Hu D, Ma L, Huntsman S, Gard CC, Leung JWT, Tice JA, Vachon CM, Cummings SR, Kerlikowske K, Ziv E. Breast cancer risk prediction using a clinical risk model and polygenic risk score. Breast Cancer Res Treat 2016;159:513-25.

14 van Veen EM, Brentnall AR, Byers H, Harkness EF, Astley SM, Sampson S, Howell A, Newman WG, Cuzick J, Evans DGR. Use of single-nucleotide polymorphisms and mammographic density plus classic risk factors for breast cancer risk prediction. JAMA Oncol 2018;4:476-82.

15 Muranen TA, Mavaddat N, Khan S, Fagerholm R, Pelttari L, Lee A, Aittomäki K, Blomqvist C, Easton DF, Nevanlinna H. Polygenic risk score is associated with increased disease risk in 52 Finnish breast cancer families. Breast Cancer Res Treat 2016;158:463-9.

16 NCCN. Clinical practice guidelines in oncology; breast cancer screening and diagnosis, 2017. Available: https://www.nccn.org/professionals/physician_gls/pdf/breastscreening.pdf [Accessed Apr 2018].

17 NICE. National Institute for health and care excellence: familial breast cancer: classification, care and managing breast cancer and related risks in people with a family history of breast cancer, 2013. Available: www.nice.org.uk/guidance/cg164 [Accessed Apr 2018].

18 IKNL. Netherlands comprehensive Cancer Organisation: Oncoline Mammacarcinoom, 2017. Available: www.oncoline.n//richtlijn/item/index.php?pagina=/richtlijn/item/ pagina.php\&richtlijn id=885 [Accessed Apr 2018].

19 de Bock GH, Schutte M, Krol-Warmerdam EMM, Seynaeve C, Blom J, Brekelmans CTM, Meijers-Heijboer H, van Asperen CJ, Cornelisse CJ, Devilee P, Tollenaar RAEM, Klijn JGM. Tumour characteristics and prognosis of breast cancer patients carrying the germline CHEK2*1100delC variant. J Med Genet 2004;41:731-5.

20 Oldenburg RA, Kroeze-Jansema KHG, Houwing-Duistermaat JJ, Bayley J-P, Dambrot C, van Asperen CJ, van den Ouweland AMW, Bakker B, van Beers EH, Nederlof PM, Vasen H, Hoogerbrugge N, Cornelisse CJ, Meijers-Heijboer H, Devilee P. Genomewide linkage scan in Dutch hereditary non-BRCA1/2 breast cancer families identifies 9q21-22 as a putative breast cancer susceptibility locus. Genes Chromosomes Cancer 2008;47:947-56

21 Delaneau O, Marchini J, Zagury J-F. A linear complexity phasing method for thousands of genomes. Nat Methods 2012;9:179-81.

22 Howie BN, Donnelly P, Marchini J. A flexible and accurate genotype imputation method for the next generation of genome-wide association studies. PLoS Genetics 2009;5:e1000529.

23 Deelen P, Menelaou A, van Leeuwen EM, Kanterakis A, van Dijk F, Medina-Gomez C, Francioli LC, Hottenga JJ, Karssen LC, Estrada K, Kreiner-Møller E, Rivadeneira F, van Setten J, Gutierrez-Achury J, Westra H-J, Franke L, van Enckevort D, Dijkstra M, Byelas $H$, van Duijn CM, de Bakker PIW, Wijmenga C, Swertz MA, Genome of Netherlands Consortium. Improved imputation quality of low-frequency and rare variants in European samples using the 'Genome of The Netherlands'. Eur J Hum Genet 2014;22:1321-6.

24 Abecasis GR, Altshuler D, Auton A, Brooks LD, Durbin RM, Gibbs RA, Hurles ME, McVean GA, 1000 Genomes Project Consortium. A map of human genome variation from population-scale sequencing. Nature 2010;467:1061-73.

25 R_Core_Team. R: a language and environment for statistical computing. Vienna, Austria: R Foundation for Statistical Computing, 2017.

26 Chatterjee N, Shi J, García-Closas M. Developing and evaluating polygenic risk prediction models for stratified disease prevention. Nature Reviews Genetics 2016;17:392-406. 
27 Milne RL, Kuchenbaecker KB, Michailidou K, Beesley J, Kar S, Lindström S, Hui S, Lemaçon A, Soucy P, Dennis J, Jiang X, Rostamianfar A, Finucane H, Bolla MK, McGuffog L, Wang Q, Aalfs CM, Adams M, Adlard J, Agata S, Ahmed S, Ahsan H, Aittomäki K, Al-Ejeh F, Allen J, Ambrosone CB, Amos Cl, Andrulis IL, Anton-Culver H, Antonenkova NN, Arndt V, Arnold N, Aronson KJ, Auber B, Auer PL, Ausems MGEM, Azzollini J, Bacot F, Balmaña J, Barile M, Barjhoux L, Barkardottir RB, Barrdahl M, Barnes D, Barrowdale D, Baynes C, Beckmann MW, Benitez J, Bermisheva M, Bernstein L, Bignon Y-J, Blazer KR, Blok MJ, Blomqvist C, Blot W, Bobolis K, Boeckx $B$, Bogdanova NV, Bojesen A, Bojesen SE, Bonanni B, Børresen-Dale A-L, Bozsik A, Bradbury AR, Brand JS, Brauch $\mathrm{H}$, Brenner $\mathrm{H}$, Bressac-de Paillerets B, Brewer $C$, Brinton L, Broberg P, Brooks-Wilson A, Brunet J, Brüning T, Burwinkel B, Buys SS, Byun J, Cai Q, Caldés T, Caligo MA, Campbell I, Canzian F, Caron O, Carracedo A, Carter BD, Castelao JE, Castera L, Caux-Moncoutier V, Chan SB, Chang-Claude J, Chanock SJ, Chen X, Cheng T-YD, Chiquette J, Christiansen H, Claes KBM, Clarke CL, Conner T, Conroy DM, Cook J, Cordina-Duverger E, Cornelissen S, Coupier I, Cox A, Cox DG, Cross SS, Cuk K, Cunningham JM, Czene K, Daly MB, Damiola F, Darabi H, Davidson R, De Leeneer K, Devilee P, Dicks E, Diez O, Ding YC, Ditsch N, Doheny KF, Domchek SM, Dorfling CM, Dörk T, dos-Santos-Silva I, Dubois S, Dugué P-A, Dumont M, Dunning AM, Durcan L, Dwek M, Dworniczak B, Eccles D, Eeles R, Ehrencrona $H$, Eilber $U$, Ejlertsen $B$, Ekici $A B$, Eliassen $A H$, Engel C, Eriksson $M$, Fachal L, Faivre L, Fasching PA, Faust U, Figueroa J, Flesch-Janys D, Fletcher O, Flyger H, Foulkes WD, Friedman E, Fritschi L, Frost D, Gabrielson M, Gaddam P, Gammon MD, Ganz PA, Gapstur SM, Garber J, Garcia-Barberan V, García-Sáenz JA, Gaudet MM, Gauthier-Villars M, Gehrig A, Georgoulias V, Gerdes A-M, Giles GG, Glendon G, Godwin AK, Goldberg MS, Goldgar DE, González-Neira A, Goodfellow P, Greene MH, Alnæs GIG, Grip M, Gronwald J, Grundy A, Gschwantler-Kaulich D, Guénel P, Guo Q, Haeberle L, Hahnen E, Haiman CA, Håkansson N, Hallberg E, Hamann U, Hamel N, Hankinson S, Hansen TVO, Harrington P, Hart SN, Hartikainen JM, Healey CS, Hein A, Helbig S, Henderson A, Heyworth J, Hicks B, Hillemanns $P_{\text {, }}$ Hodgson S, Hogervorst FB, Hollestelle A, Hooning MJ, Hoover B, Hopper JL, Hu C, Huang G, Hulick PJ, Humphreys K, Hunter DJ, Imyanitov EN, Isaacs C, Iwasaki M, Izatt $L$, Jakubowska $A$, James $P$, Janavicius $R$, Janni $W$, Jensen $U B$, John $E M$, Johnson $\mathrm{N}$, Jones K, Jones $\mathrm{M}$, Jukkola-Vuorinen $A$, Kaaks R, Kabisch M, Kaczmarek K, Kang D, Kast K, Keeman R, Kerin MJ, Kets CM, Keupers M, Khan S, Khusnutdinova E, Kiiski J, Kim S-W, Knight JA, Konstantopoulou I, Kosma V-M, Kristensen VN, Kruse TA, Kwong A, Lænkholm A-V, Laitman Y, Lalloo F, Lambrechts D, Landsman K, Lasset C, Lazaro C, Le Marchand L, Lecarpentier J, Lee A, Lee E, Lee JW, Lee MH, Lejbkowicz F, Lesueur F, Li J, Lilyquist J, Lincoln A, Lindblom A, Lissowska J, Lo W-Y, Loibl S, Long J, Loud JT, Lubinski J, Luccarini C, Lush M, MacInnis RJ, Maishman T, Makalic E, Kostovska IM, Malone KE, Manoukian S, Manson JE, Margolin S, Martens JWM, Martinez ME, Matsuo K, Mavroudis D, Mazoyer S, McLean C, Meijers-Heijboer $H$, Menéndez P, Meyer J, Miao H, Miller A, Miller N, Mitchell G, Montagna M, Muir K, Mulligan AM, Mulot C, Nadesan S, Nathanson KL, Neuhausen SL, Nevanlinna H, Nevelsteen I, Niederacher D, Nielsen SF, Nordestgaard BG, Norman A, Nussbaum RL, Olah E, Olopade OI, Olson JE, Olswold C, Ong K-ren, Oosterwijk JC, Orr N, Osorio A, Pankratz VS, Papi L, Park-Simon T-W, Paulsson-Karlsson Y, Lloyd R, Pedersen IS, Peissel B, Peixoto A, Perez JIA, Peterlongo P, Peto J, Pfeiler G, Phelan CM, Pinchev M, Plaseska-Karanfilska D, Poppe B, Porteous ME, Prentice R, Presneau N, Prokofieva D, Pugh E, Pujana MA, Pylkäs K, Rack B, Radice P, Rahman N, Rantala J, Rappaport-Fuerhauser C, Rennert G, Rennert HS, Rhenius V, Rhiem K, Richardson A, Rodriguez GC, Romero A, Romm J, Rookus MA, Rudolph A, Ruediger T, Saloustros E, Sanders J, Sandler DP, Sangrajrang S, Sawyer EJ, Schmidt DF, Schoemaker MJ, Schumacher F, Schürmann P, Schwentner L, Scott C, Scott RJ, Seal S, Senter L, Seynaeve C, Shah M, Sharma P, Shen C-Y, Sheng X, Shimelis H, Shrubsole MJ, Shu X-O, Side LE, Singer CF, Sohn C, Southey MC, Spinelli JJ, Spurdle AB, Stegmaier C, Stoppa-Lyonnet D, Sukiennicki G, Surowy H, Sutter C, Swerdlow A, Szabo Cl, Tamim RM, Tan YY, Taylor JA, Tejada M-I, Tengström M, Teo SH, Terry MB, Tessier DC, Teulé A, Thöne K, Thull DL, Tibiletti MG, Tihomirova L, Tischkowitz M, Toland AE, Tollenaar RAEM, Tomlinson I, Tong L, Torres D, Tranchant M, Truong T, Tucker K, Tung N, Tyrer J, Ulmer H-U, Vachon C, van Asperen CJ, Van Den Berg D, van den Ouweland AMW, van Rensburg EJ, Varesco L, Varon-Mateeva R, Vega A, Viel A, Vijai J, Vincent D, Vollenweider J, Walker L, Wang Z, Wang-Gohrke S, Wappenschmidt B, Weinberg CR, Weitzel JN, Wendt C, Wesseling J, Whittemore AS, Wijnen JT, Willett W, Winqvist R, Wolk A, Wu AH, Xia L, Yang XR, Yannoukakos D, Zaffaroni D, Zheng W, Zhu B, Ziogas A, Ziv E, Zorn KK, Gago-Dominguez M, Mannermaa A, Olsson H, Teixeira MR, Stone J, Offit K, Ottini L, Park SK, Thomassen M, Hall P, Meindl A, Schmutzler RK, Droit A, Bader GD, Pharoah PDP, Couch FJ, Easton DF, Kraft P, Chenevix-Trench G, García-Closas M, Schmidt MK, Antoniou AC, Simard J. Identification of ten variants associated with risk of estrogen-receptor-negative breast cancer. Nature Genetics 2017:49:1767-78

28 Robson ME, Reiner AS, Brooks JD, Concannon PJ, John EM, Mellemkjaer L, Bernstein L, Malone KE, Knight JA, Lynch CF, Woods M, Liang X, Haile RW, Duggan DJ, Shore RE, Smith SA, Thomas DC, Stram DO, Bernstein JL, on behalf of the WECARE Study Collaborative Group. Association of common genetic variants with contralateral breast cancer risk in the WECARE Study. J Natl Cancer Inst 2017;109.

29 Evans DG, Brentnall A, Byers H, Harkness E, Stavrinos P, Howell A, Newman WG, Cuzick J, FH-risk study Group. The impact of a panel of 18 SNPs on breast cancer risk in women attending a UK familial screening clinic: a case-control study. J Med Genet 2017:54:111-3.

30 Khera AV, Chaffin M, Aragam KG, Haas ME, Roselli C, Choi SH, Natarajan P, Lander ES, Lubitz SA, Ellinor PT, Kathiresan S. Genome-wide polygenic scores for common diseases identify individuals with risk equivalent to monogenic mutations. Nat Genet 2018:50:1219-24.

31 Mavaddat N, Michailidou K, Dennis J, Lush M, Fachal L, Lee A, Tyrer JP, Chen T-H, Wang Q, Bolla MK, Yang X, Adank MA, Ahearn T, Aittomäki K, Allen J, Andrulis IL, Anton-Culver H, Antonenkova NN, Arndt V, Aronson KJ, Auer PL, Auvinen P, Barrdahl M, Beane Freeman LE, Beckmann MW, Behrens S, Benitez J, Bermisheva M, Bernstein L, Blomqvist C, Bogdanova NV, Bojesen SE, Bonanni B, Børresen-Dale A-L, Brauch $\mathrm{H}$, Bremer M, Brenner $\mathrm{H}$, Brentnall A, Brock IW, Brooks-Wilson A, Brucker SY, Brüning T, Burwinkel B, Campa D, Carter BD, Castelao JE, Chanock SJ, Chlebowski R, Christiansen $\mathrm{H}$, Clarke CL, Collée JM, Cordina-Duverger E, Cornelissen S, Couch FJ, Cox A, Cross SS, Czene K, Daly MB, Devilee P, Dörk T, Dos-Santos-Silva I, Dumont M, Durcan L, Dwek M, Eccles DM, Ekici AB, Eliassen AH, Ellberg C, Engel C, Eriksson M, Evans DG, Fasching PA, Figueroa J, Fletcher O, Flyger H, Försti A, Fritschi L, Gabrielson M, Gago-Dominguez M, Gapstur SM, García-Sáenz JA, Gaudet MM, Georgoulias V, Giles GG, Gilyazova IR, Glendon G, Goldberg MS, Goldgar DE, González-Neira A, Grenaker Alnæs GI, Grip M, Gronwald J, Grundy A, Guénel P, Haeberle L, Hahnen E, Haiman CA, Håkansson N, Hamann U, Hankinson SE, Harkness EF, Hart SN, He W, Hein A, Heyworth J, Hillemanns P, Hollestelle A, Hooning MJ, Hoover RN, Hopper JL, Howell A, Huang G, Humphreys K, Hunter DJ, Jakimovska M, Jakubowska A, Janni W, John EM, Johnson $N$, Jones ME, Jukkola-Vuorinen A, Jung A, Kaaks R, Kaczmarek K, Kataja V, Keeman R, Kerin MJ, Khusnutdinova E, Kiiski Jl, Knight JA, Ko Y-D, Kosma V-M, Koutros S, Kristensen VN, Krüger U, Kühl T, Lambrechts D, Le Marchand L, Lee E, Lejbkowicz F, Lilyquist J, Lindblom A, Lindström S, Lissowska J, Lo W-Y, Loibl S, Long J, Lubiński J, Lux MP, MacInnis RJ, Maishman T, Makalic E, Maleva Kostovska I, Mannermaa A, Manoukian S, Margolin S, Martens JWM, Martinez ME, Mavroudis D, McLean C, Meindl A, Menon U, Middha P, Miller N, Moreno F, Mulligan AM, Mulot C, Muñoz-Garzon VM, Neuhausen SL, Nevanlinna H, Neven P, Newman WG, Nielsen SF, Nordestgaard BG, Norman A, Offit K, Olson JE, Olsson H, Orr N, Pankratz VS, Park-Simon T-W, Perez JIA, Pérez-Barrios C, Peterlongo P, Peto J, Pinchev M, PlaseskaKaranfilska D, Polley EC, Prentice R, Presneau N, Prokofyeva D, Purrington K, Pylkäs K, Rack B, Radice P, Rau-Murthy R, Rennert G, Rennert HS, Rhenius V, Robson M, Romero A, Ruddy KJ, Ruebner M, Saloustros E, Sandler DP, Sawyer EJ, Schmidt DF, Schmutzler RK, Schneeweiss A, Schoemaker MJ, Schumacher F, Schürmann P, Schwentner L, Scott C, Scott RJ, Seynaeve C, Shah M, Sherman ME, Shrubsole MJ, Shu X-O, Slager S, Smeets A, Sohn C, Soucy P, Southey MC, Spinelli JJ, Stegmaier C, Stone J, Swerdlow AJ, Tamimi RM, Tapper WJ, Taylor JA, Terry MB, Thöne K, Tollenaar RAEM, Tomlinson I, Truong T, Tzardi M, Ulmer H-U, Untch M, Vachon CM, van Veen EM, Vijai J, Weinberg $C R$, Wendt C, Whittemore AS, Wildiers H, Willett W, Winqvist R, Wolk A, Yang XR, Yannoukakos D, Zhang Y, Zheng W, Ziogas A, Dunning AM, Thompson DJ, ChenevixTrench G, Chang-Claude J, Schmidt MK, Hall P, Milne RL, Pharoah PDP, Antoniou AC, Chatterjee N, Kraft P, García-Closas M, Simard J, Easton DF, ABCTB Investigators, kConFab/AOCS Investigators, NBCS Collaborators. Polygenic risk scores for prediction of breast cancer and breast cancer subtypes. Am J Hum Genet 2019;104.

32 Buys SS, Sandbach JF, Gammon A, Patel G, Kidd J, Brown KL, Sharma L, Saam J, Lancaster J, Daly MB. A study of over 35,000 women with breast cancer tested with a 25-gene panel of hereditary cancer genes. Cancer 2017;123:1721-30.

33 Couch FJ, Shimelis H, Hu C, Hart SN, Polley EC, Na J, Hallberg E, Moore R, Thomas A, Lilyquist J, Feng B, McFarland R, Pesaran T, Huether R, LaDuca H, Chao EC, Goldgar $D E$, Dolinsky JS. Associations between cancer predisposition testing panel genes and breast cancer. JAMA Oncol 2017;3:1190-6.

34 Lee A, Mavaddat N, Wilcox AN, Cunningham AP, Carver T, Hartley S, Babb de Villiers C, Izquierdo A, Simard J, Schmidt MK, Walter FM, Chatterjee N, Garcia-Closas M, Tischkowitz M, Pharoah P, Easton DF, Antoniou AC. BOADICEA: a comprehensive breast cancer risk prediction model incorporating genetic and nongenetic risk factors. Genet Med 2019. 